\title{
Moorean tree snail survival revisited: a multi-island genealogical perspective
}

\author{
Taehwan Lee ${ }^{1}$, John B Burch ${ }^{1}$, Trevor Coote ${ }^{2}$, Paul Pearce-Kelly ${ }^{3}$, \\ Carole Hickman ${ }^{4}$, Jean-Yves Meyer ${ }^{5}$ and Diarmaid Ó Foighil*1
}

\begin{abstract}
Address: ${ }^{1}$ Museum of Zoology and Department of Ecology and Evolutionary Biology, University of Michigan, 1109 Geddes Ave, Ann Arbor, MI 48109-1079, USA, 2Partulid Global Species Management Programme, B.P. 44921 Fare Tony, Papeete, Tahiti, Polynésie Française, ${ }^{3}$ Zoological Society of London, Regents Park, London, UK, ${ }^{4}$ University of California, Department of Integrative Biology, 3060 VLSB \#3140, Berkeley, CA 94720-3140, USA and 5 Délégation à la Recherche, Ministère de l'Education, de l'Enseignement Supérieur et de la Recherche, B.P. 20981 Papeete, Tahiti, Polynésie Française

Email: Taehwan Lee - taehwanl@umich.edu; John B Burch - jbburch@umich.edu; Trevor Coote - partula2003@yahoo.co.uk; Paul PearceKelly - Paul.Pearce-Kelly@zsl.org; Carole Hickman - caroleh@berkeley.edu; Jean-Yves Meyer - jean-yves.meyer@recherche.gov.pf; Diarmaid Ó Foighil* diarmaid@umich.edu

* Corresponding author
\end{abstract}

Published: 18 August 2009

BMC Evolutionary Biology 2009, 9:204 doi:10.1/86/147|-2/48-9-204
Received: 4 March 2009

Accepted: 18 August 2009

This article is available from: http://www.biomedcentral.com//47/-2/48/9/204

(C) 2009 Lee et al; licensee BioMed Central Ltd.

This is an Open Access article distributed under the terms of the Creative Commons Attribution License (http://creativecommons.org/licenses/by/2.0), which permits unrestricted use, distribution, and reproduction in any medium, provided the original work is properly cited.

\begin{abstract}
Background: The mass extirpation of the island of Moorea's endemic partulid tree snail fauna, following the deliberate introduction of the alien predator Euglandina rosea, represents one of the highest profile conservation crises of the past thirty years. All of the island's partulids were thought to be extirpated by 1987, with five species persisting in zoos, but intensive field surveys have recently detected a number of surviving wild populations. We report here a mitochondrial $(\mathrm{mt})$ phylogenetic estimate of Moorean partulid wild and captive lineage survival calibrated with a reference museum collection that pre-dates the predator's introduction and that also includes a parallel dataset from the neighboring island of Tahiti.
\end{abstract}

Results: Although severe winnowing of Moorea's mt lineage diversity has occurred, seven of eight (six Partula; two Samoana) partulid tip clades remain extant. The extinct $\mathrm{mt}$ clade occurred predominantly in the $P$. suturalis species complex and it represented a major component of Moorea's endemic partulid treespace. Extant Moorean mt clades exhibited a complex spectrum of persistence on Moorea, in captivity, and (in the form of five phylogenetically distinct sister lineages) on Tahiti. Most notably, three Partula taxa, bearing two multi-island $m t$ lineages, have survived decades of $E$. rosea predation on Moorea ( $P$. taeniata) and in the valleys of Tahiti ( $P$. hyalina and $P$. clara). Their differential persistence was correlated with intrinsic attributes, such as taxonomy and $\mathrm{mt}$ lineages, rather than with their respective within-island distribution patterns.

Conclusion: Conservation efforts directed toward Moorean and Tahitian partulids have typically operated within a single island frame of reference, but our discovery of robust genealogical ties among survivors on both islands implies that a multi-island perspective is required. Understanding what genetic and/or ecological factors have enabled Partula taeniata, $P$. hyalina and $P$. clara to differentially survive long-term direct exposure to the predator may provide important clues toward developing a viable long term conservation plan for Society Island partulid tree snails. 


\section{Background}

Oceanic islands have never been connected to continental landmasses and receive their terrestrial biotas solely through trans-oceanic dispersal and subsequent in situ diversification [1]. Hot spot archipelagoes, in particular, are fecund cladogenic settings, and these chronologically arrayed island chains frequently accumulate species-rich endemic radiations that are of exceptional interest to evolutionary biologists [2-4]. Because they have evolved in isolation, endemic island species often lack highly developed defensive or competitive abilities [5-7], and this renders them exceptionally vulnerable to introduced continental competitors and predators $[1,8,9]$.

One of the most pronounced recent cases of oceanic island mass extirpation has involved the rapid extinction in the wild of the large majority of the 61 described endemic Society Islands partulid tree snails (4 Samoana and 57 Partula species) following the deliberate introduction of the alien carnivorous land snail Euglandina rosea [10-13]. The rationale for the introduction was a biological control program aimed at another alien mollusc, the giant African land snail, Lissachatina fulica, and the predator was released on Tahiti in 1974, on Moorea in 1977 , and on other Society Islands in the 1980s and 1990s [14].

Euglandina rosea's devastating effect on non-target Society Island endemic tree snail populations is best documented for the island of Moorea [10,15]. Within a decade, all 9 Moorean partulids (7 Partula and 2 Samoana species) were deemed extirpated, but prescient interventions led to the successful establishment of off-island captive populations for most of the island's Partula species in international zoos and universities [15-17]. Five endemic Moorean Partula species ( $P$. taeniata, $P$. suturalis, $P$. tohiveana, $P$. mooreana and $P$. mirabilis) have been successfully maintained in captivity for over two decades by The Partulid Global Species Management Programme, and two species ( $P$. exigua and $P$. aurantia) are extinct [13]. No captive populations exist for Society Island Samoana species. In 1994, an experimental reestablishment of captive-reared $P$. taeniata, $P$. suturalis and $P$. tohiveana was attempted by releasing them into a $20 \times 20 \mathrm{~m}^{2}$ predator-proof snail field reserve erected in a Moorean valley. However, field maintenance issues led to repeated predator incursions and the experiment was terminated in 1998 [18].

The loss of the Society Island's endemic tree snails is compounded by their scientific prominence as the subject of classic studies in zoology, population biology and evolutionary genetics for over a century [19-24]. Moorean Partula spp., in particular, were the focus of much of this research, and have been intensively studied by B. Clarke, J. Murray, M. Johnson and their associates over a number of decades. The resulting picture is a complicated one in which six of the seven morphologically and ecologically well-defined Moorean species collectively formed two species complexes: 1) $P$. taeniata and $P$. exigua; 2) $P$. suturalis, $P$. tohiveana, $P$. mooreana and $P$. aurantia. The seventh species, $P$. mirabilis, could hybridize with either complex [22]. Moorean Partula spp. showed a potential for gene flow, either directly or indirectly, among all seven taxa, resulting in a lack of concordance among morphology, molecules and degree of reproductive isolation [2528].

All Moorean partulid species were thought to be extirpated in the wild by 1987 [15] and, until recently, it looked as if Society Island partulids would survive only in captivity [13]. However, intensive on-going field surveys have detected scattered relict populations on a number of islands, including seven on Moorea. A relict Moorean population of Samoana attenuata has been monitored since 1996 by C. Hickman, and this species also persists on Tahiti [14,29] and on Raiatea [30]. Six surviving populations of the Moorean endemic Partula taeniata have been detected since 2000. This latter species was formerly distributed throughout the island and exhibited regional variation in shell phenotype [31], allozyme profile [32] and mitochondrial $(\mathrm{mt})$ genetic structure $[25,27]$.

The primary goal of our study was to assess genealogically the remnant wild Moorean partulid populations by placing them in a phylogeographic framework. A single island phylogenetic perspective is insufficient because Samoana attenuata has a multi-island distribution [33] and Partula taeniata contains divergent mt lineages that collectively form robust taxonomically polyphyletic clades with different subsets of Moorean and Tahitian congeners $[25,34]$. Moorea and Tahiti are neighboring islands separated by a mere $17 \mathrm{~km}$ of ocean. They are the largest members of the Society Island archipelago's eastern "Windward Islands/Iles $d u$ Vent" sub-group and support all of the sub-group's partulid populations. Moorea is the older of the two, and allozyme and morphological analyses have identified it as the source of Tahiti's Partula species [35], although there may have been some backmigration from Tahiti to southern Moorea [26]. Our goal therefore was to build a combined Moorean/Tahitian phylogeny that incorporated extant wild populations, extant captive populations and historical museum samples, the latter collected by J.B. Burch in 1970, prior to the introduction of Euglandina rosea.

A recent phylogenetic study of Tahitian wild, captive and historical museum tree snails found that at least some members of all five primary historical Tahitian Partula mt clades remain extant, primarily in montane refuge populations [36]. This result was somewhat unexpected, given that three of Tahiti's eight Partula species are extinct [13]. 
However, Society Island partulid taxonomic designations are predominantly conchological $[20,21]$, and they are often poorly-corroborated by molecular markers, although this is further complicated by incongruence among genetic marker sets [25-28,36,37]. In this present study, we were particularly interested in testing for cryptic genealogical links among surviving Windward Island partulid populations on Moorea and on Tahiti. Our results show that although much of Moorea's tree snail mitochondrial diversity (including one of the primary tip clades) has been lost, a surprisingly representative genealogical sub-sample collectively persists in captivity, in the wild on Moorea and, in the form of five phylogenetically distinct sister lineages, on Tahiti.

\section{Results and discussion Windward Island Overview}

Combining our novel data (82 distinct haplotypes from 161 snails) with preexisting $\mathrm{mt}$ COI datasets [30,36,37] produced a total Windward Island genotyped partulid sample size of 457 snails. Although this malacofauna has experienced extreme extinction pressure in recent decades, access to museum and captive specimens enabled us to incorporate genotypes from six extinct species (three Moorean) as well as from the five extirpated species (four Moorean) that persist in captivity [13]. Consequently, we have almost complete nominal species taxonomic representation: 16 out of the 17 Windward Island taxa listed in a recent study [13] in addition to the endemic Tahitian Samoana burchi. The missing species, Partula cytherea, has not been seen since its 1920 's discovery on a remote Tahitian interior mountain slope [38] and it is now presumed extinct [13].

Figure 1 gives an overview of the Windward Island partulid mt COI phylogeny recovered. The most trenchant topological feature was the well-supported reciprocal monophyly of Samoana and Partula taxa, which corroborated numerous lines of anatomical $[33,39]$, allozymic $[35,40]$ and nuclear rDNA $[41,42]$ evidence of their distinctiveness. In the Partula clade, the basal Windward Island lineages were exclusively Tahitian, and the Moorean haplotypes formed six tip clades, three of which (Moorea 1-3) contained the large majority of the island's haplotypic diversity and occupied the most derived portion of Windward Island tree space (Figure 1). The remaining three Moorean tip clades (Moorea 4-6) were interspersed with Tahitian lineages, and two of them formed robust exclusive sister relationships with Tahitian tip clades: Moorea 4 and Tahiti 5; Moorea 5 and Tahiti 1. The most robust internal stem branch supported approximately half of the Partula clade treespace (Moorea 1-4; Tahiti 5) and, with the exception of $P$. nodosa (Tahitian clade 3 ; [36]), its taxonomic composition was consistent with Murray et al's [25] most common Windward Island
Partula mt RFLP genotype (A). The absence of major clades exclusive to captive and wild samples (Figure 1) implied that the reference museum collection may be broadly representative of pre-collapse 1970 Moorean Partula mt diversity. Nevertheless, two divergent extant haplotypes (one from a wild $P$. taeniata on the summit of Mt. Tohiea; the other from a captive P. s. vexillium sampled in Fareaito) lack 1970 phylogenetic matches (Figure 1). Detailed discussion of each Moorean tip clade follows below.

\section{Moorean Clade I}

Figure 2 gives a fine-scale view of Moorean Clade 1, showing the taxonomic identity and the geographic origin of each constituent snail genotyped for mt COI. Focusing first on Moorean haplotypes, this clade was taxonomically polyphyletic, but in a topologically structured manner. Derived Moorean lineages, comprising approximately $80 \%$ of this clade's topology, were exclusively composed of Partula taeniata (widely distributed across the island) and $P$. exigua (Figure 2). These two species readily hybridize under laboratory conditions [22] and collectively form the P. taeniata species complex [23]. Clade 1 basal lineages were sourced from the south central part of the island and most were obtained from $P$. mooreana and $P$. tohiveana, both members of the P. suturalis species complex [23]. This basal segment of Clade 1 treespace was broadly congruent with the $P$. taeniata/P. mooreana/P. tohiveana $\mathrm{mt}$ Cytochrome B clade previously recovered from many of the same southern localities [34]. Although P. exigua is extinct, $P$. taeniata Moorean Clade 1 lineages persist both in captivity and in three central/south island wild populations: Haumi and Maatea valleys, as well as on upper slopes of Mt. Tohiea (Figure 2). Basal Clade 1 lineages of $P$. mooreana and $P$. tohiveana survive only in captivity but a remnant wild $P$. taeniata population persists in Morioahu valley (Figure 2).

Moorean Clade 1 lineages initially appeared to be restricted to that island because no constituent haplotypes had been encountered in Lee et al's $[36,37]$ extensive genotyping of Tahitian wild, captive and historical museum tree snails. However, four Tahitan snails from a recently discovered extant population of Partula clara in Tiapa Valley (unsampled by Burch in 1970) all shared a haplotype that surprisingly nested firmly within Moorean Clade 1, sister to a Moorean Puutu Valley population of $P$. exigua (Figure 2). Crampton recognized the Tiapa (Aoua, in his terminology) Valley population as a distinct subspecies, $P$. clara incrassa, stating that it was extraordinarily distinct from nominal conspecifics in adjacent valleys in that it had longer thinner shells, peculiar color morphs including unique banded mutants, thinner shells and lips and some specimens with a trace of a pillar tooth [20]. Our extant wild Tiapa Valley snails are conchologically indistinguishable 


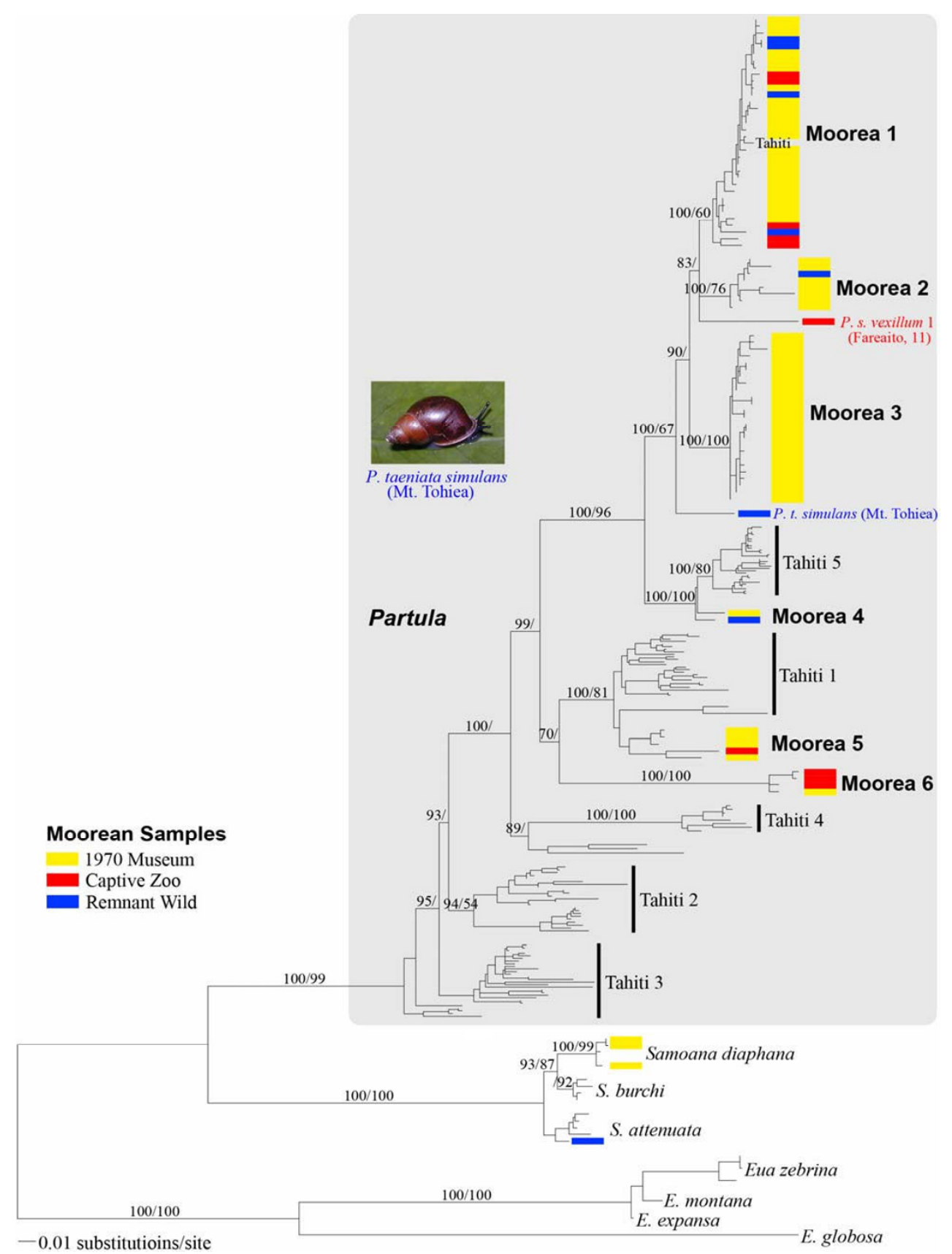

\section{Figure I}

Maximum likelihood tree showing an overview of the inferred phylogenetic relationships of Windward Island partulid mt COI genotypes. The partulid genus Eua, restricted to central Pacific islands in Samoa, American Samoa and Tonga, served as the outgroup [42] and the grey background applied to the Partula clade visually distinguishes the two ingroup genera. Partula tip clades were taxonomically polyphyletic and the six Moorean tip clades are numbered in bold, as were the five Tahitian clades previously characterized [36]. Terminal Moorean haplotypes are color-coded according to their sample source: Burch 1970 Museum specimens; captive snails; extant wild populations. Two divergent Moorean mt haplotypes were recovered from single snails and are labeled individually: a captive $P$. suturalis vexillium and an extant wild Mt. Tohiea $P$. taeniata simulans (identified by J. Murray). A photograph of the latter specimen, taken in the field by J.Y. Meyer, is inserted. Support levels are given above major internal branches; Bayesian posterior probabilities $(>70)$ on the left and maximum parsimony bootstrap support values $(>50)$ on the right. 
from Crampton's voucher specimens of $P$. c. incrassa (see Additional File 1) and the haplotype they carry is phylogenetically distinct from all other Tahitian partulids (Figure 1), including members of the primary $P$. clara/hyalina clade in adjacent valleys [37]. Snails bearing Moorean Clade 1 mitochondria therefore appear to have established a discrete founder population in this Tahitian valley, where they now represent the only surviving partulids (T. Coote pers. observ.), and this clade remains tenuously extant on both Moorea ( $P$. taeniata) and Tahiti ( $P$. c. incrassa), as well as in captivity.

\section{Moorean Clade 2}

Prior to the introduction of Euglandina rosea, three Moorean species (Partula taeniata, P. suturalis and P. mirabilis) had two areas of sympatry, the smaller occurring on the Mt. Rotui Peninsula [22,23]. We obtained a well-supported and phylogenetically distinctive $\mathrm{mt}$ clade (Moorea Clade 2) from a sub-sample of $1970 \mathrm{Mt}$. Rotui Peninsula (Matapoopoo Valley) P. mirabilis and P. taeniata specimens (Figure 3 ). This polyphyletic result was unsurprising because $P$. mirabilis can hybridize with both $P$. taeniata and $P$. suturalis species complexes [22]. Moorean Clade 2 appears to have been restricted to the Mt. Rotui Peninsula (Figure 3) and was not represented in the captive populations, none of which were sourced there. However, this mt lineage remains precariously extant; five biopsies from a nearby surviving population of $P$. taeniata, discovered by C. Hickman in 2002, all produced a Clade 2 haplotype (Figure 3). These survivors persist in an unusual mangrove fern micro-habitat fringing Opunohu Bay, exhibit a variety of shell-color morphs, and may be protected from Euglandina rosea incursions by a brackish water moat (C. Hickman unpubl. observ.).

\section{Moorean Clade 3}

This major endemic Moorean clade was recovered from 11 out of 13 Burch 1970 sampling stations and was present in high frequencies in central and eastern parts of the island (Figure 4). Moorean Clade 3 was almost exclusively (36/40 snails) composed of $P$. suturalis (including nominal subspecies) and $P$. aurantia, both members of the $P$. suturalis species complex $[23,32]$ that readily hybridized in the laboratory [22]. The other Clade 3 taxon consisted of four Matapoopoo Valley specimens of Partula mirabilis propinqua [22], two of which shared a haplotype with Puutu Valley P. suturalis specimens (Figure 4). A notable feature of this clade was the conspicuous absence of $P$. mooreana and $P$. tohiveana, the remaining two members of the P. suturalis species complex [23]. They placed instead within Moorean Clade 1, together with members of the $P$. taeniata species complex (Figure 2; [34]). It may be pertinent that $P$. mooreana and $P$. tohiveana showed little or no ability to hybridize with $P$. suturalis under laboratory conditions [22]. Those reproductive incompatibilities, coupled with their observed mt phylogenetic distinctiveness (Figures 2, 4; [34]), undermine the case for inclusion of $P$. mooreana and $P$. tohiveana in the $P$. suturalis species complex.

Both Partula aurantia and P. m. propinqua are now presumed extinct. Two P. suturalis subspecies survive in captivity. They were originally sourced from one central valley ( $P$. s. vexillum: Fareaito; see topological placement in Figure 1) and two southern valleys (P. s. vexillum: Vaianai; P. s. strigosa: Maatea), but none of the genotyped captive specimens bore Moorean Clade $3 \mathrm{mt}$ lineages (Figure 4). It would appear that Moorean Clade 3, a major endemic component of the island's historical partulid mt tree space, may well be extinct.

\section{Moorean Clade 4}

Eight individuals of Partula taeniata nucleola sampled from a northwestern Moorean valley (Faatoai) by J. B. Burch in 1970 all carried a haplotype (Moorean Clade 4; Figure 5) that was phylogenetically divergent from all other genotyped Moorean museum and captive partulids, including captive P. t. nucleola sourced from that same valley (Moorean Clade 1; Figures 1,2). Goodacre also recovered two divergent $P$. taeniata $\mathrm{mt}$ haplogroups from independent historical Faatoai Valley samples [27]. One haplogroup was relatively rare in Faatoai, but widespread throughout the island, as is Moorean Clade 1 (Figure 2); the other was predominant in western valleys, including Faatoai and Moruu [27]. A newly discovered remnant Moruu Valley population of $P$. taeniata provided the first Moorean phylogenetic match to the Burch 1970 P. t. nucleola lineage (Moorean Clade 4; Figure 5). We therefore consider it likely that our Moorean Clade 4 and Goodacre's P. taeniata western haplogroup [27] both represent the same lineage and that, though absent from captive populations, it still remains extant in Moruu Valley.

Viewed from a single-island perspective, Moorean Clade 4 seems relatively unimportant: it lacks on-island sister lineages, represents a minor component of the island's historical partulid mt tree space, had a restricted original distribution and is not represented in captive populations (Figures 1,5 ; [27]). However, taking a multi-island perspective revealed these Moorean Partula taeniata mt lineages to be part of a larger mt clade with a substantial Windward Island, and regional archipelagic distribution. Moorean Clade 4 has a robust and exclusive sister relationship with a major Tahitian mt lineage comprising two nominal species, Partula hyalina and P. clara (Tahitian Clade 5; Figures 1, 5; with the exception of the Tiapa Valley population of $P$. c. incrassa, Figure 2). Tahitian $P$. hyalina and $P$. clara snails have also proven to be differentially resistant to Euglandina rosea predation. Although these two nominal taxa collectively represented only circa 


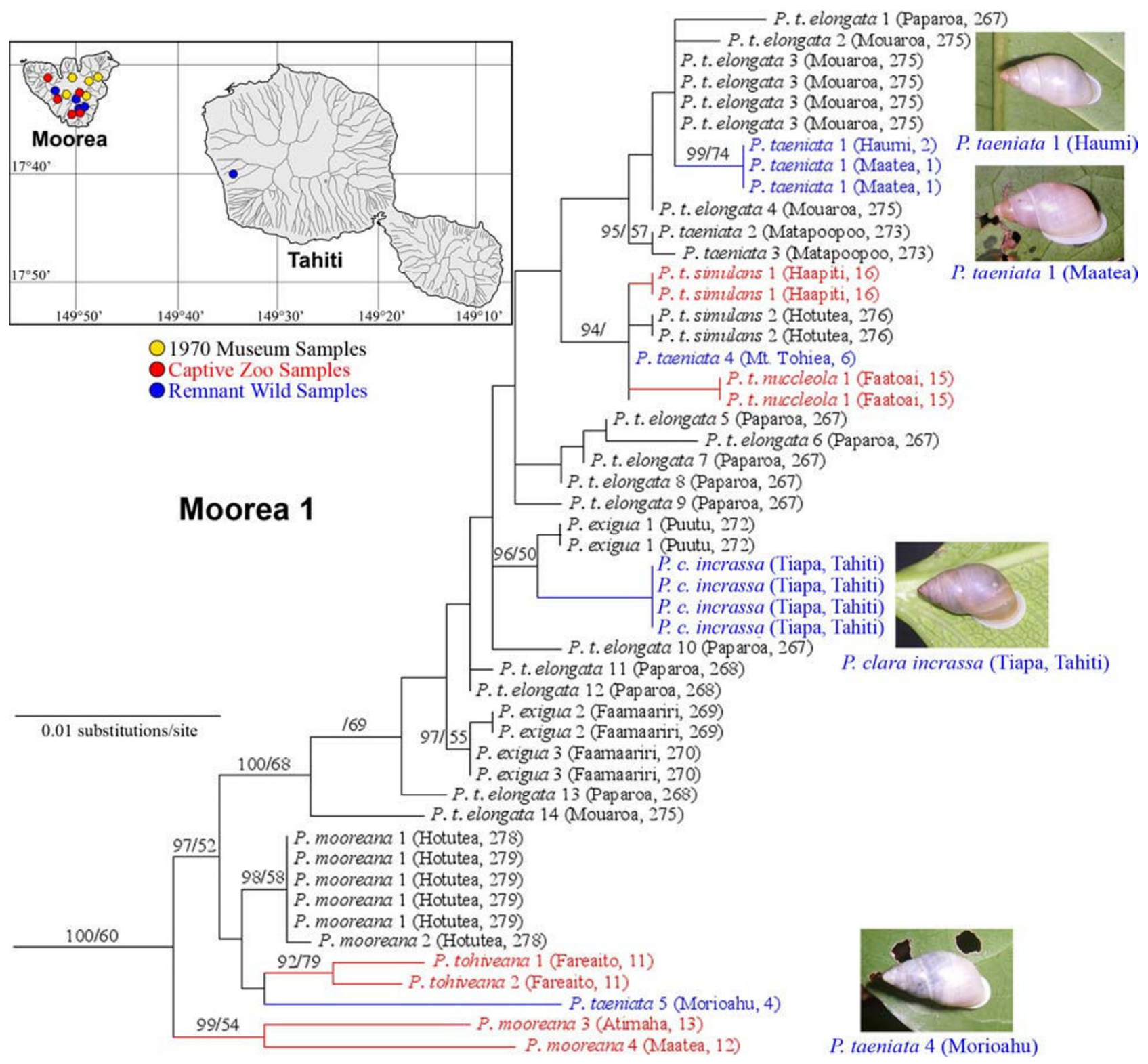

Figure 2

A detailed view of Moorean Clade I (Figure I) mt COI genotypes. The taxonomic identity of each haplotype is given together with its geographic origin in Moorea, or Tahiti (valley name and sampling location code). The taxonomic labels are color-coded according to source: Burch 1970 museum specimens; captive snails; extant wild populations. The insert map shows the geographic origins of museum, captive and extant Clade I mt genotypes obtained from I4 locations throughout Moorea and from a single location (Tiapa Valley) in Tahiti. Insert photographs, taken in the field by T. Coote, are shown for three surviving populations of $P$. taeniata on Moorea and the single population of $P$. clara incrassa on Tahiti. Support levels are given above branches; Bayesian posterior probabilities $(>70)$ on the left and maximum parsimony bootstrap support values (> 50) on the right.

5\% of historical Tahitian valley Partula spp. populations [20], they now form $100 \%$ of the surviving populations in numerous Tahitian valleys [14], the latest estimate being 33 valleys (T. Coote, unpubl. observ.). Multiple 1970-era Tahitian haplotypes were recovered from genotyped extant wild and captive Tahitian $P$. hyalina and $P$. clara snails and also from extant $P$. hyalina anthropogenic founder populations in the Cook and Austral Islands, two neighboring hot spot archipelagoes (Figure 5; $[36,37]$ ). Regional wild snail populations bearing members of this 


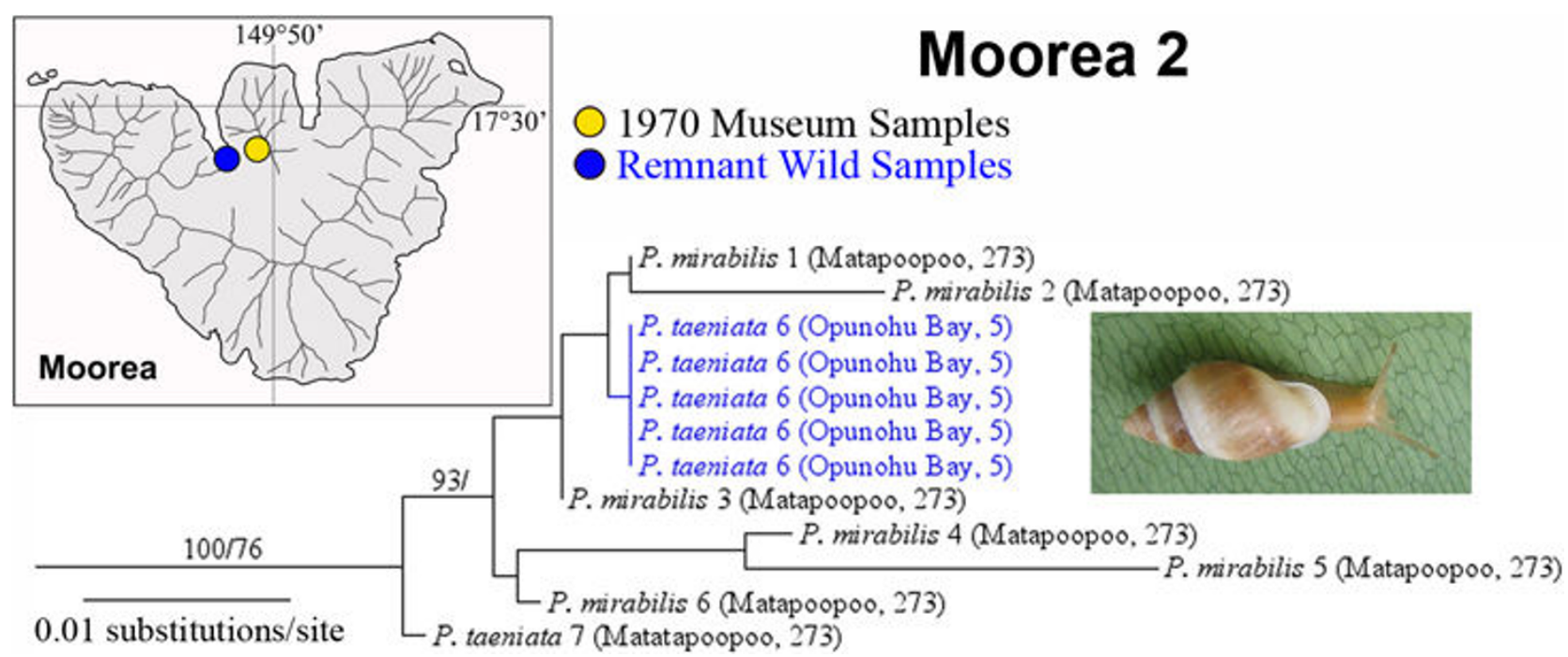

Figure 3

A magnified view of Moorean Clade 2 (Figure I) mt COI genotypes. The taxonomic identity of each haplotype is given together with its geographic origin in either Matapoopoo Valley (Burch 1970 museum samples) or the Opunohu Bay mangrove fern locality (extant population). The insert photograph, taken in the field by C. Hickman, shows one of the 5 surviving wild $P$. taeniata that were biopsied and sequenced. Support levels are given above branches; Bayesian posterior probabilities $(>70)$ on the left and maximum parsimony bootstrap support values $(>50)$ on the right.

phylogenetically-distinctive $\mathrm{mt}$ lineage (Moorea 4 + Tahiti 5) therefore survive tenuously in the presence of Euglandina rosea on Moorea and on Tahiti and thrive in its absence on the Cook and Austral archipelagoes (Figure 5; [37]).

\section{Moorean Clade 5}

A second phylogenetically-distinct Moorean mt lineage (Moorean Clade 5) with a robust Tahitian sister clade was recovered from museum samples of Partula suturalis vexillium and from museum and captive samples of $P$. mirabilis, all sourced from northwest/central valleys (Figure 6). The P. s. vexillium snails from the northwestern valley Faatoai placed firmly in Moorean Clade 5 (Figure 6), unlike their Moorean Clade 3 conspecifics sampled across the northcentral and northeast of the island (Figure 4). Moorean Clade 5 museum samples also contained $P$. mirabilis from both of its geographically-disjunct [22] populations: Mt. Rotui (Matapoopoo Valley) and central Moorea (Mouaroa Valley). Murray and Clarke found that both $P$. mirabilis populations hybridized readily [22], and this is consistent with our finding of a very close mt phylogenetic association among this taxon's Matapoopoo and Mouaroa clade 5 snails (Figure 6). Nevertheless, it should be kept in mind that the Matapoopoo P. mirabilis 1970 sample was highly heterogeneous in its mt lineage com- position. It also contained snails with Moorean Clade 2 haplotypes (Figure 3; shared with $P$. taeniata) as well as $P$. $m$. propinqua individuals bearing Moorean clade 3 haplotypes (Figure 4; shared with P. suturalis and P. aurantia). These results corroborate Murray and Clarke's view [22] of $P$. mirabilis as a species that could hybridize with both $P$. taeniata and $P$. suturalis species complexes.

Moorean Clade 5 is now apparently extirpated in the wild, but a constituent haplotype survives in a captive P. mirabilis population, originally sourced from Fareaito Valley (Figure 6). Taking a multi-island perspective, Moorean Clade 5 is part of a larger and phylogenetically-distinctive Windward Island $\mathrm{mt}$ lineage that incorporates an exclusive Tahitian sister clade: Tahiti 1 (Figures 1, 6; [36]) and that collectively has a taxonomic composition consistent with Murray et al's [25] mt RFLP genotype "P". Tahiti Clade 1 contained two nominal species, $P$. affinis and $P$. otaheitana, had an island-wide distribution, and two known populations persist: $P$. affinis in captivity and a remnant montane population of $P$. otaheitana on $\mathrm{Mt}$. Atara (Figure 6; [36]). Unlike the two other nested Moorean/Tahitian Partula spp. clades (Figures 2, 5), snails bearing this multi-island $\mathrm{mt}$ lineage appear incapable of surviving in Windward Island valleys in the presence of Euglandina rosea. 


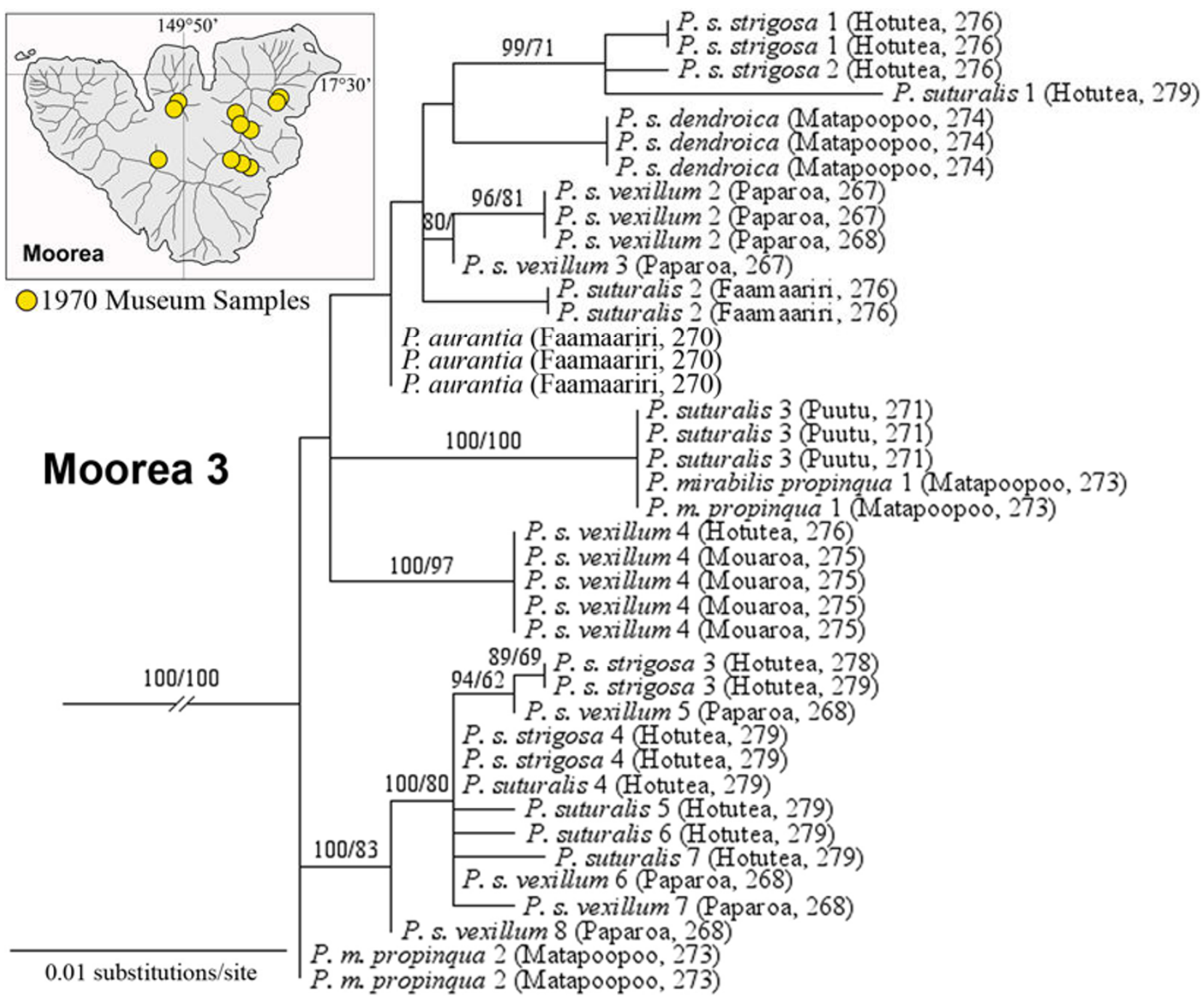

Figure 4

A detailed view of Moorean Clade 3 (Figure I) mt COI genotypes. This tip clade was exclusively composed of museum specimens sampled by J. B. Burch in 1970 from II sampling stations (see insert map). The taxonomic identity of each haplotype is given together with its geographic origin. Support levels are given above branches; Bayesian posterior probabilities $(>70)$ on the left and maximum parsimony bootstrap support values $(>50)$ on the right.

\section{Moorean Clade 6}

Murray et al. [25] found that southern Moorean populations of Partula suturalis had a highly distinctive mtDNA RFLP genotype that differed markedly from conspecific northern populations. Our limited sampling of southern $P$. suturalis confirmed this result. We recovered a divergent tip clade (Moorea Clade 6; Fig 7) from captive lines of two subspecies sourced from Maatea and Vaianai Valleys, together with a single $P$. s. strigosa snail sampled in 1970 from Hotutea Valley (Figure 7). The other four 1970 Hotutea $P$. s. strigosa individuals genotyped from that same sampling station (276) placed in Moorean Clade 3
(Figure 4). Moorean Clade 6 appears to have been extirpated in the wild but persists in captivity.

\section{Samoana}

Three allozymically-corroborated Windward Island Samoana morphospecies have been recorded [33,43]: S. attenuata (Moorea and Tahiti); S. diaphana (Moorea and Tahiti) and S. burchi (Tahiti only). No captive populations exist but lyophilized 1970 museum tissue was available for all three species, although from single island populations only of S. attenuata (Tahiti) and S. diaphana (Moorea). Genotyped museum samples were phylogenetically ana- 


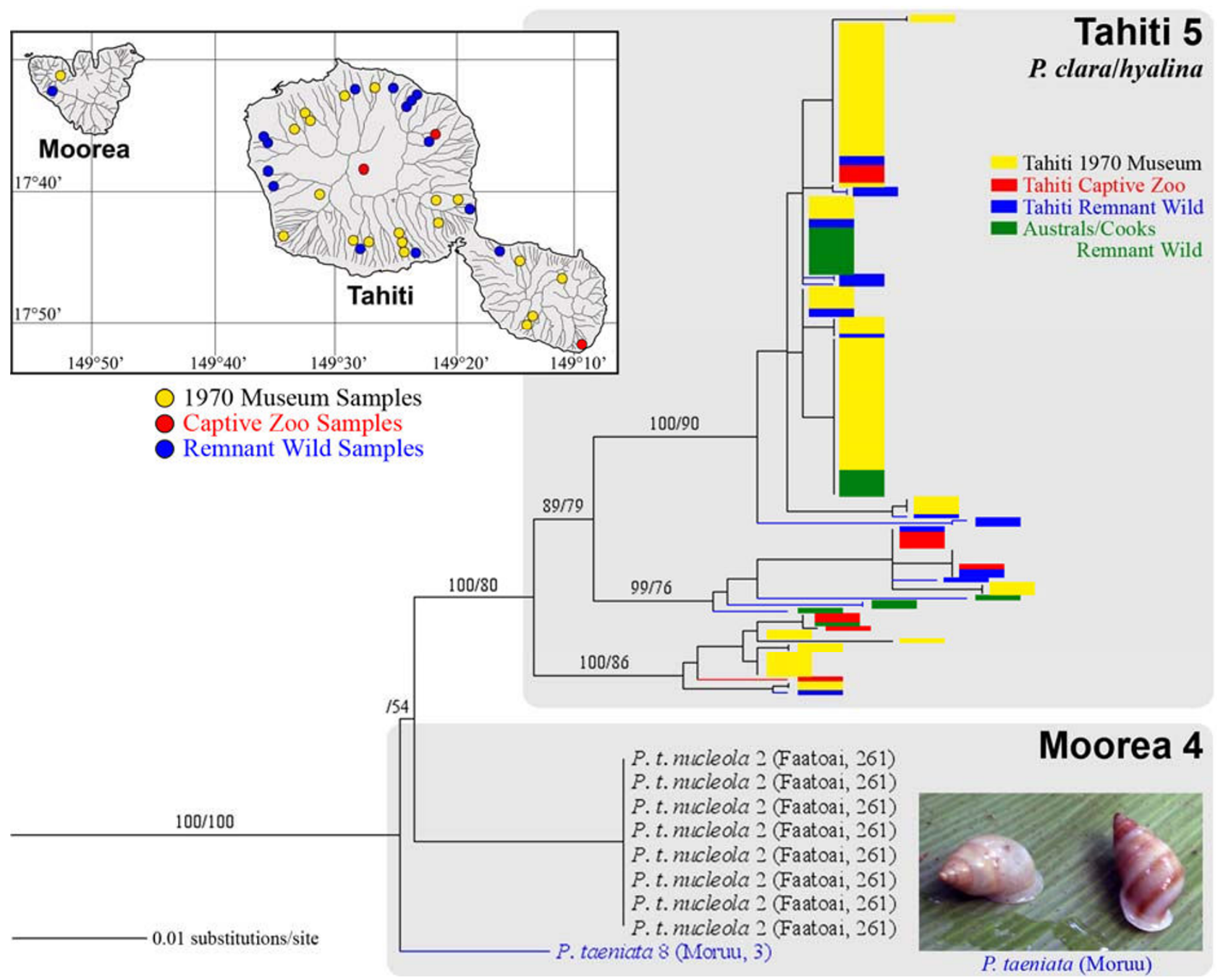

\section{Figure 5}

Topological, taxonomic and distributional details of Moorean Clade 4 (Figure I), and its sister clade, Tahiti 5 [36]. Moorean Clade 4 haplotypes were recovered from $P$. taeniata individuals in two northwestern valleys (see insert map) and an insert photograph, taken in the field by T. Coote, is shown of surviving Moruu Valley specimens. Snails bearing Tahiti Clade 5 haplotypes remain extant on Tahiti (composed of $P$. hyalina and $P$. clara [36,37]) and on the Cook and Austral archipelagoes ( $P$. hyalina only [37]). Support levels are given above branches; Bayesian posterior probabilities $(>70)$ on the left and maximum parsimony bootstrap support values $(>50)$ on the right.

lyzed together with sequences obtained from tissue biopsies of surviving $S$. attenuata populations on Tahiti and Moorea [14] and on Raiatea [30], together with recently discovered extant Tahitian montane populations of $S$. diaphana and S. burchi. Our phylogenetic results confirm that $S$. attenuata survives on Moorea and that all three taxa persist in the wild on Tahiti (Figure 8; but see also Additional File 2 for possible persistence of $S$. diaphana on Moorea). Individual haplotypes were not shared among the multi-island samples of $S$. attenuata and $S$. diaphana, and the former species did not form a Windward Island clade: Tahitian haplotypes instead clustered with the Raiatean sample.

Topological details of the Samoana clade also corroborated earlier allozyme studies that revealed strikingly different phylogenetic profiles among co-occurring Samoana and Partula taxa [43]. These distinctions included the much lower collective genetic diversity levels of Samoana species (compare relative generic treespaces in Figure 1) and their more pronounced mt phylogenetic cohesiveness (all three Samoana species were reciprocally mono- 


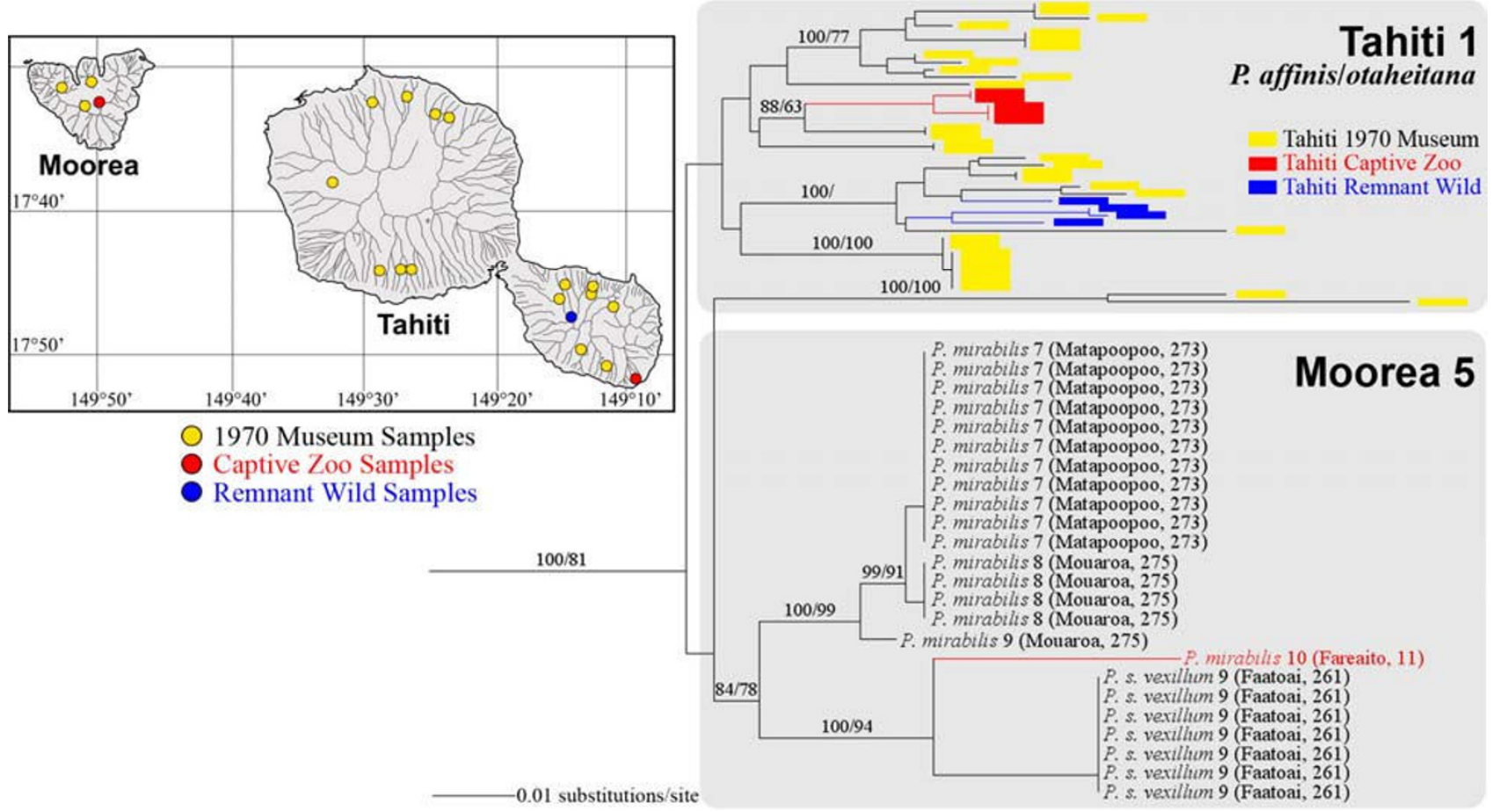

\section{Figure 6}

A detailed view of Moorean mt Clade 5 (Figure I) and its paraphyletic sister mt clade, Tahiti I [36]. The taxonomic identity of each Moorea Clade 5 haplotype is given together with its geographic origin and sample source: Burch 1970 Museum $P$. mirabilis and $P$. suturalis vexillium or captive $P$. mirabilis. Tahitian Clade I lineages were composed of $P$. otaheitana and $P$. affinis [36]. Support levels are given above branches; Bayesian posterior probabilities ( $>70)$ on the left and maximum parsimony bootstrap support values $(>50)$ on the right.

phyletic, including the multi-island taxa; Figure 8). Samoana and Partula lineages therefore appear to have experienced quite distinct patterns of cladogenesis in the Windward Islands and, post Euglandina rosea introduction, they also have experienced differential patterns of extirpation and survival. This is a particularly interesting result, given that these three taxa were originally much scarcer than co-occurring Partula species in the Society Islands [33].

\section{Summary discussion}

One of the primary challenges faced in constructing a meaningful phylogeny of a largely extirpated fauna concerns the issue of comprehensiveness; how confident are we that our historical reference samples contain the primary Moorean endemic lineages? Although our taxonomic sample of Windward Island Partulidae was almost complete, this in itself was insufficient because of the poor correlation of nominal taxonomy with molecular markers [26]. Nevertheless, our novel results were in good agreement with previous independent $\mathrm{mt}$ characterizations of these taxa $[25,27,28,34]$, both within Moorea (e.g., geographic distributions and taxonomic composition of the primary clades) and among the two islands, apart from a small number of relatively minor issues such as the presence of the Tahitian species Partula nodosa within the primary Windward Island mt RFLP lineage [25]. We are therefore confident that our historical reference Moorean dataset probably contains the primary Moorean lineages and that it can be used to assess what fraction of the island's endemic mt treespace has survived in captivity and/or in the wild.

Our Windward Island dataset yields a novel, and somewhat complex, multi-island genealogical perspective on Moorean partulid survival. Only one of eight historical Moorean partulid tip clades (six Partula spp.; two Samoana spp.) is extinct. Unfortunately, the extinct lineage (Moorea Clade 3 ) encompassed the bulk of the $P$. suturalis species complex, and lacked Tahitian sister lineages (Figures $1,4)$. The seven extant clades exhibited a heterogeneous spectrum of persistence: on Moorea, in captivity and also on Tahiti (Moorean Clade 1); on Moorea, with sister lineages on Tahiti, on other archipelagoes, and in captivity (Moorea Clade 4); on Moorea, with sister lineages on Tahiti (S. attenuata); on Moorea (Moorea Clade 2); in cap- 


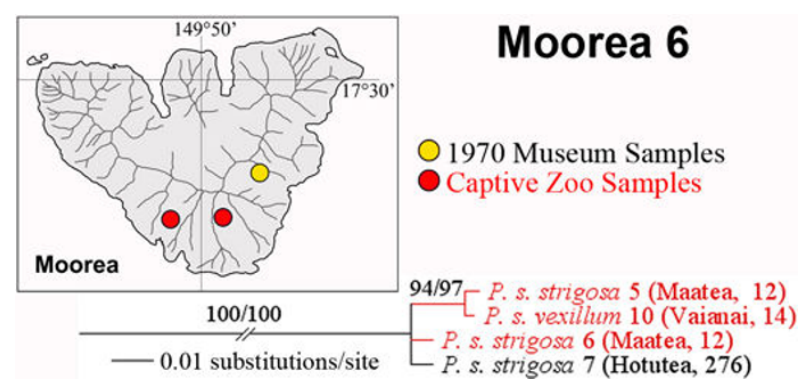

Figure 7

Topological, taxonomic and distributional details of Moorean Clade 6 (Figure I) haplotypes. They were obtained from Burch 1970 museum and captive samples of Partula suturalis strigosa and captive $P$. s. vexillium. Support levels are given above branches; Bayesian posterior probabilities $(>70)$ on the left and maximum parsimony bootstrap support values $(>50)$ on the right.

tivity, with sister lineages on Tahiti and also in captivity (Moorea Clade 5); sister lineages on Tahiti (S. diaphana); in captivity (Moorea Clade 6).

Our assessment of Moorean partulid survival comes with an obvious caveat concerning its broader utility; do these results have relevance to understanding historical Moorean partulid whole organism genealogies, and their present day conservation status? Fortunately, this did not appear to be an issue for Windward Island Samoana species where there was excellent taxonomic/mt lineage congruence (Figure 8). However, Society Island partulid taxonomy may be poorly corroborated by molecular markers and, in addition, different nuclear (allozymes and nRNA) and organellar genetic marker sets may also be incongruent [25-28,36,37]. Although we cannot address this issue directly using allozymes or high-resolution nuclear markers, two lines of indirect data indicate that our museum, captive and remnant wild mt genealogies do have broader biological and conservation significance. First, the taxonomic composition of our clades is in good agreement with the results of Moorean breeding experiments [22], e.g., reproductive compatibility of $P$. taeniata and $P$. exigua; compatibility of $P$. suturalis and $P$. aurantia; incompatibility of $P$. mooreana and $P$. tohiveana with $P$. suturalis, compatibility of $P$. mirabilis with both $P$. taeniata and $P$. suturalis. Second, the ability of Partula spp. populations to persist on Moorea and in Tahitian valleys in the long-term presence of Euglandina rosea appears to be correlated with both taxonomy and mt phylogeography.

Gerlach [44] proposed that impaired predator performance at altitude would allow the persistence of Society Island partulids in montane refuges and we see evidence of this in Tahiti where substantial montane populations preserve multiple $\mathrm{mt}$ clades that have been extirpated at lower altitudes

[36]. Moorea has a much smaller montane (> $1000 \mathrm{~m}$ ) habitat than Tahiti and there is no part of the island where a representative sampling of the original in-situ diversity (taxonomic and/or mt lineage) has survived. This can be readily visualized by comparing the distribution pattern of surviving Partula taeniata populations (Figure 9; locations 1-6) with the pre-Euglandina rosea introduction distribution maps of the island's species of Partula [23]. Although the two widespread Moorean species, Partula taeniata and $P$. suturalis, originally had almost identical over-lapping distributions on Moorea [23], all six known surviving populations of Moorean Partula are exclusively composed of P. taeniata. Differential survival is also evident among mutually exclusive $\mathrm{mt}$ clades: Moorean Clades 1, 2 and 4 for $P$. taeniata (all of which persist in the wild); Moorean Clades 3, 5 and 6 for P. suturalis (all of which are apparently extirpated in the wild). There is no apparent correlation of survival with altitude on Moorea: extant $P$. taeniata are found at sea-level (Opunohu Bay), at lower altitudes (Maatea Valley, $180 \mathrm{~m}$ ), and also just below $(1150 \mathrm{~m})$ the summit $(1207 \mathrm{~m})$ of Mt. Tohiea, the highest point on the island (Figure 1).

Predation models predict extirpation of Partula spp. populations within 3 years of initial Euglandina rosea contact [45]. Snails bearing four Moorean mt lineages (Clades 2, 3, 5 (+ its sister clade Tahiti 1) and 6) meet this prediction in that they have not persisted in the presence of the predator, surviving in the wild only in insulated micro-habitats such as the Opunohu Bay mangrove fern enclave (Moorea Clade 2; Figure 3) or in a high altitude montane refuge (Tahiti Clade 1; Figure 6; [36]). In contrast, snail populations bearing one of two multi-island $\mathrm{mt}$ lineages (Moorea Clade 1; Moorea 4 \& Tahiti 5) have successfully survived three decades of direct exposure to the predator on Moorea and in many Tahitian valleys.

It is unclear at present what biological attributes, genetic and/or ecological, underlie this differential persistence: Crampton [20,21] documented relatively higher fecundities in Partula hyalina and P. clara (Tahiti Clade 5), but not in P. taeniata (Moorean Clades 1, 4). Detailed field studies of the surviving populations are urgently required and these may yield clues toward developing a viable longterm conservation plan for Society Island partulid tree snails. Goodacre's mt population study of $P$. taeniata historical populations documented the presence of a pronounced cline involving a western haplogroup (probably our Moorean Clade 4) and an island-wide haplogroup (probably our Moorean Clade 1) in northwestern valleys that was not corroborated by variation in 6 polymorphic 


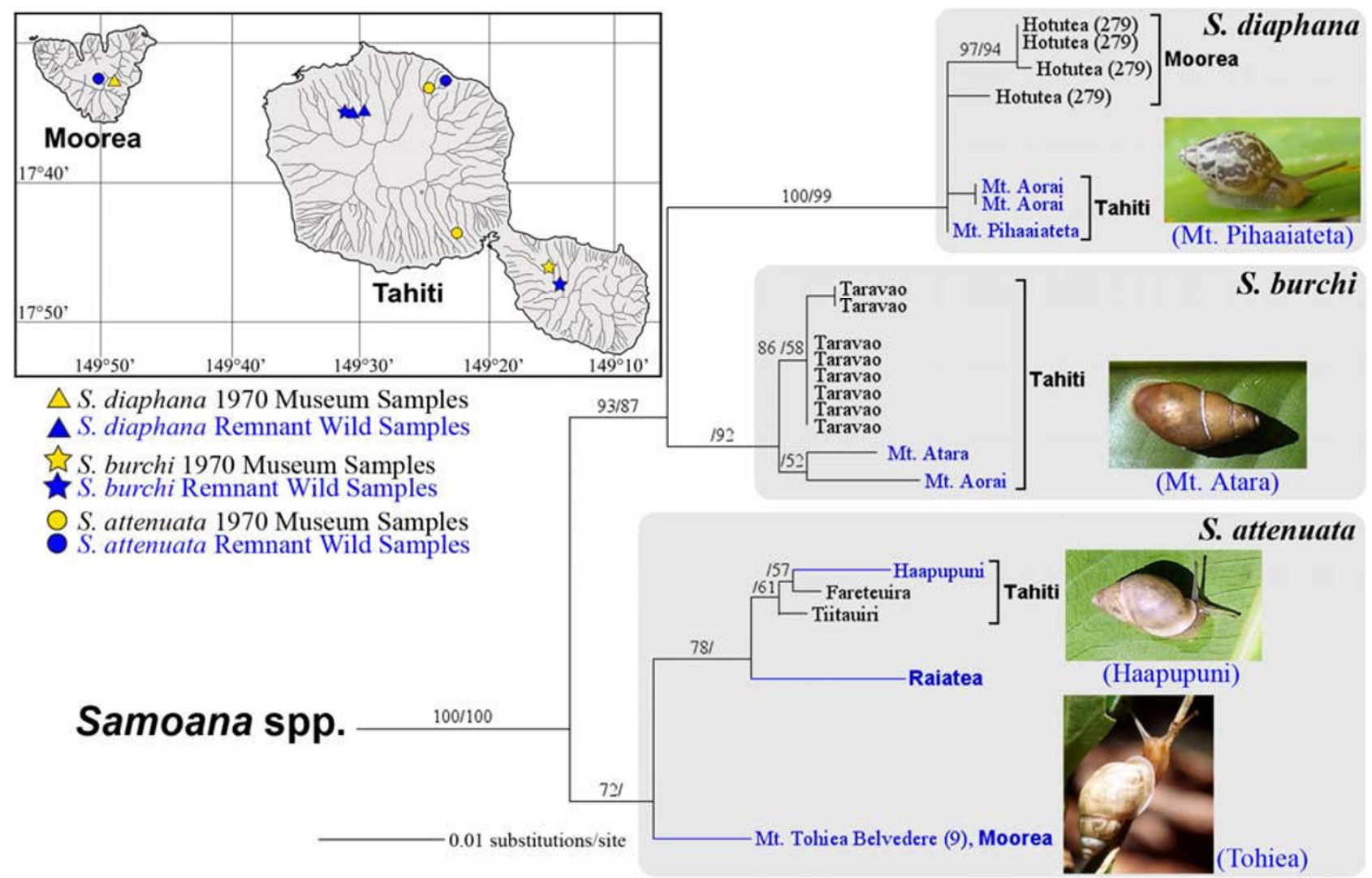

Figure 8

A magnified view of the Samoana mt COI clade (Figure I). It shows the topological placement and distribution of Burch 1970 museum specimens together with those of extant wild samples. These include S. diaphana (Moorea and Tahiti, photograph of extant Tahitian snail by B. Holland); S. burchi, (Tahiti only, photograph of extant snail by T. Coote) and S. attenuata [Moorea and Tahiti, photographs of extant wild snails by C. Hickman (Moorea) and T. Coote (Tahiti)]. A mt genotype obtained from a surviving Raiatean population [30] is also included. Note that S. attenuata is known to persist in additional Tahitian valleys [14]. Support levels are given above branches; Bayesian posterior probabilities $(>70)$ on the left and maximum parsimony bootstrap support values $(>50)$ on the right.

allozyme loci [27]. It is therefore possible that surviving $P$. taeniata populations bearing these two $\mathrm{mt}$ clades may share common sets of hypothetical nuclear genomeencoded "resistance" traits, but this remains to be determined. Irrespective of the underlying mechanisms, the differential resilience exhibited by $P$. taeniata, $P$. hyalina and $P$. clara identifies them as the most promising captive candidate lineages for future Windward Island reestablishment attempts.

\section{Conclusion}

Conservation efforts directed toward Moorean and Tahitian partulids have typically operated within a single island frame of reference $[14,18,29]$. However, there is an increasing appreciation among conservation biologists for the importance of evolutionary and ecological processes in effective conservation planning [46] and the multi- island genealogical relationships of Moorean partulid taxa (Figure 1), specifically the presence of five phylogenetically-distinct sister lineages on Tahiti, provide a broader Windward Island evolutionary perspective on Moorean tree snail survival. Our results imply that, for many endemic partulid lineages, it may be apt to consider Moorea and Tahiti in a more integrated fashion, where proposed conservation initiatives on one of the islands are evaluated within a collective Windward Island genealogical context. This may be especially pertinent in the case of the genealogically-linked surviving lineages of $P$. taeniata, $P$. hyalina and $P$. clara, but it is also potentially relevant for conservation measures involving Thaitian montane refuges where snails with robust phylogenetic ties to extirpated Moorean lineages still persist (Figure 6). Multi-island genealogical perspectives will probably prove to be of proactive conservation value not only for 


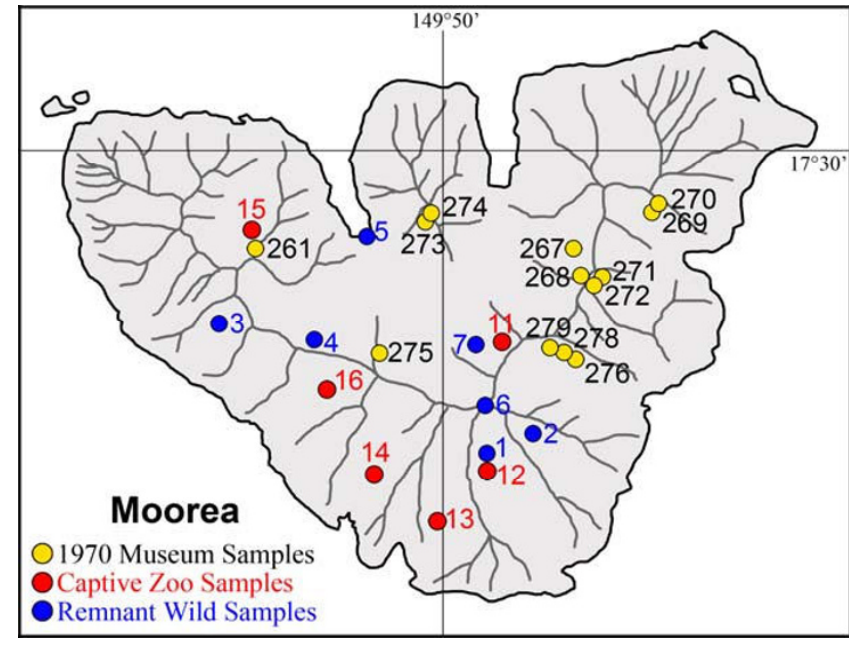

Figure 9

Map of the island of Moorea showing partulid sampling locations. Interior lines represent major ridges. The labeling code for J. B. Burch's 1970 sampling stations was as follows: 26 I: Faatoai Valley, northern slope of Mt. Tautuapae (350 m altitude); 267: Paparoa V. ( $100 \mathrm{~m}$ ); 268: Paparoa V. (300 m); 269: Faamaariri V. (I $50 \mathrm{~m})$; 270: Faamaariri V. (300 m); 27I: Puutu V. (250 m); 272: Puutu V. (400 m); 273: Matapoopoo V. (I50-200 m); 274: Matapoopoo V. (400 m); 275: Mouaroa V. (200-300 m); 276: Hotutea V. northeastern ridge $(400 \mathrm{~m}) ; 278$ : Hotutea $\mathrm{V}$. northeastern ridge (480 m); 279: Hotutea V. northeastern ridge $(620 \mathrm{~m})$. Extant wild populations were detected and biopsied in the following locations: I: Maatea Valley (I80 m; June 2007); 2: Haumi V. (June 2007); 3: Moruu V. (June 2005); 4: Morioahu V. (September 2007); 5: Opunohu Bay mangrove (November 2006); 6: Mt. Tohiea (I 150 m; January 2002 and September 2006); 7: Partula Reserve, Mt. Tohiea Belvedere (October 2006). Captive zoo populations were sourced from the following valleys (exact locations within valleys are uncertain): I I: Fareaito V.; I2: Maatea V.; I 3: Atimaha V.; I4: Vaianai V.; I5: Faatoai V.; I6: Haapiti V.

Windward Island partulids, but also for the critically endangered terrestrial biotas of many other Pacific hot spot archipelagoes $[47,48]$.

\section{Methods \\ Sampling}

See Figure 10 for an overview of the sampling locations and the taxonomic identity of partulid snails genotyped in this study. Voucher information is available in Additional File 3 together with sampling details for previously genotyped partulid snails $[30,36,37]$ incorporated into the phylogenetic analyses.

J. B. Burch and associates sampled Moorean partulids in October 1970 at 13 stations (Figure 9). Specimens of all nominal Moorean partulid species except for Partula tohiveana and Samoana attenuata were airmailed alive to the University of Michigan Museum of Zoology (UMMZ) where foot tissues were lyophilized and shells retained as vouchers. We selected 125 lyophilized Moorean individuals for genotyping based on Crampton's species and subspecies-level taxonomy (Figure 10; Additional File 3). From 1980 to 1985, emergency field sampling of six populations (Figure 9) led to the establishment of a number of captive Moorean tree snail lines $[15,17]$. Sixteen captive snails representing five Moorean Partula species [P. mirabilis, $P$. mooreana, $P$. tohiveana, $P$. taeniata (subspecies $P$. $t$. nucleoli, and P. t. simulans) and P. suturalis (subspecies $P$. s. vexillum and $P$. s. strigosa)] were supplied by the International Partulid Conservation Programme for genotyping. From 2002-2006, a small number of biopsied tissue samples were obtained from extant Moorean populations, preserved in 95\% ethanol and forwarded for genotyping (Figure 10). These included a specimen of Samoana attenuata from immediately below the Afareaito Partula Reserve in the upper Oponuhu Valley and specimens of newly discovered Partula taeniata populations from a variety of locations: Maatea, Haumi and Moruu valleys; a mangrove fern habitat in Opunohu Bay; and two temporally distinct $(2002,2006)$ samples from just below (1150 $\mathrm{m})$ the summit (1207 $\mathrm{m}$ ) of Mt. Tohiea, the highest point on the island (Figure 9, Additional File 3). Biopsies from newly discovered extant Tahitian populations of $P$. clara (Tiapa Valley), S. attenuata (Haapupni Valley) and putative S. burchi (Mt. Atara, Mt. Aorai) and S. diaphana (Mt. Aorai, Mt. Pihaaiateta) that were not included in previous studies [36,37] were also genotyped.

\section{Molecular Data}

Total genomic DNA was isolated using a DNeasy Tissue Kit (Qiagen) according to the manufacturer's instructions. A 655 nucleotide (nt) mt COI target fragment was amplified with GoTaq DNA Polymerase (Promega, Madison, WI) using the "universal" primer pair LCO1490/ HCO2198 [49] and a negative control (no template) was included in each amplification run. After 2 min denatuation at $95^{\circ} \mathrm{C}$, an initial annealing temperature of $65^{\circ} \mathrm{C}$ was decreased by $2^{\circ} \mathrm{C} /$ cycle $\left(30 \mathrm{sec}\right.$ denaturing at $95^{\circ} \mathrm{C}$, $40 \mathrm{sec}$ annealing and $1 \mathrm{~min}$ extension at $72^{\circ} \mathrm{C}$ ) until the final annealing temperature $\left(45^{\circ} \mathrm{C}\right)$ was reached and subsequently maintained for an additional 30 cycles. Doublestranded products were isolated on 1\% agarose gels, excised over UV light, and extracted using a QIAquick gel extraction kit (Qiagen, Valencia, CA). Both strands of the amplified fragments were directly cycle-sequenced, using the PCR primers, by the University of Michigan's Sequencing Core Facility. All DNA sequences obtained have been deposited in GenBank (EU832996-EU833099).

\section{Phylogenetic analyses}

The resulting chromatograms were edited by comparing both strands using Sequence Navigator 1.0.1 (Applied Biosystems, Foster City, CA). COI sequences were aligned 


\begin{tabular}{|c|c|c|c|c|c|}
\hline Species & Island & Valley Name & $\begin{array}{c}\text { Locality } \\
\text { number }\end{array}$ & $\begin{array}{l}\text { \# of snails } \\
\text { sequenced }\end{array}$ & \begin{tabular}{|c|} 
\# of \\
haplotypes
\end{tabular} \\
\hline Partula aurantia Cramption, 1932 & Moorea, Society Is. & Faamaariri & 270 & 3 & 1 \\
\hline \multirow{2}{*}{ P. exigua Crampton, 1917} & \multirow{2}{*}{ Moorea, Society Is. } & Puutu & 272 & 2 & 1 \\
\hline & & Faamaariri & 269 & 4 & 2 \\
\hline \multirow[t]{3}{*}{ P. mirabilis Crampton, 1924} & \multirow[t]{3}{*}{ Moorea, Society Is. } & Matapoopoo & 273 & 17 & 7 \\
\hline & & Mouaroa & 275 & 5 & 2 \\
\hline & & Fareaito? & $11 ?$ & 4 & 1 \\
\hline P. mi. propinqua Crampton, 1932 & Moorea, Society Is. & Matapoopoo & 273 & 4 & 2 \\
\hline \multirow[t]{3}{*}{ P. mooreana Hartman, 1880} & \multirow[t]{3}{*}{ Moorea, Society Is. } & Hotutea & 278,279 & 6 & 2 \\
\hline & & Maatea & 12 & 1 & 1 \\
\hline & & Atimaha & 13 & 1 & 1 \\
\hline \multirow[t]{3}{*}{ P. suturalis Pfeiffer, 1855} & \multirow[t]{3}{*}{ Moorea, Society Is. } & Faamaariri & 270 & 2 & 1 \\
\hline & & Puutu & 271 & 3 & 1 \\
\hline & & Hotutea & 279 & 5 & 5 \\
\hline P. s. dendroica Pfeiffer, 1853 & Moorea, Society Is. & Matapoopoo & 274 & 3 & 1 \\
\hline \multirow[t]{2}{*}{ P. suturalis strigosa Pfeiffer, 1856} & \multirow[t]{2}{*}{ Moorea, Society Is. } & Hotutea & $\begin{array}{c}276 \\
278,279\end{array}$ & 8 & 5 \\
\hline & & Maatea & 12 & 2 & 2 \\
\hline \multirow[t]{6}{*}{ P. s. vexillum Pease, 1866} & \multirow[t]{6}{*}{ Moorea, Society Is. } & Faatoai & 261 & 7 & 1 \\
\hline & & Paparoa & 267,268 & 8 & 6 \\
\hline & & Mouaroa & 275 & 4 & 1 \\
\hline & & Hotutea & 276 & 1 & 1 \\
\hline & & Fareaito & 11 & 1 & 1 \\
\hline & & Vaianai & 14 & 1 & 1 \\
\hline \multirow{7}{*}{ P. taeniata Mörch, 1850} & Moorea, Society Is. & Matapoopoo & 273 & 3 & 3 \\
\hline & & Maatea & 1 & 2 & 1 \\
\hline & & Haumi & 2 & 1 & 1 \\
\hline & & Moruu & 3 & 1 & 1 \\
\hline & & Morioahu & 4 & 1 & 1 \\
\hline & & Opunohu Bay & 5 & 5 & 1 \\
\hline & & Mt. Tohiea & 6 & 1 & 1 \\
\hline P. t. elongata Pease, 1866 & Moorea, Society Is. & Paparoa & 267 & 10 & 10 \\
\hline & & Mouaroa & 275 & 7 & 4 \\
\hline P. t. nucleola "Pease" Schmeltz, & Moorea, Society Is. & Faatoai & 261 & 8 & 1 \\
\hline 1874 & & Faatoai & 15 & 2 & 1 \\
\hline P.t. simulans Pease, 1866 & Moorea, Society Is. & Hotutea & 276 & 2 & 1 \\
\hline & & Haapiti & 16 & 2 & 1 \\
\hline & & Mt. Tohiea & 6 & 1 & 1 \\
\hline P. tohiveana Crampton, 1924 & Moorea, Society Is. & Fareaito & 11 & 2 & 2 \\
\hline P. clara Pease, 1864 & Tahiti, Society Is. & Tiapa & & 4 & 1 \\
\hline \begin{tabular}{|l} 
Tahiti Clade 1 \\
$\quad(P$. affinis/otaheitana $)$
\end{tabular} & Tahiti, Society Is. & 15 valleys & 18 sites & 42 & 27 \\
\hline \begin{tabular}{|l} 
Tahiti Clade 2 \\
$(P$. filosalotaheitana $)$
\end{tabular} & Tahiti, Society Is. & 6 valleys & 12 sites & 34 & 23 \\
\hline \begin{tabular}{|l|} 
Tahiti Clade 3 \\
(P. affinis/nodosalotaheitanal \\
producta)
\end{tabular} & Tahiti, Society Is. & 14 valleys & 18 sites & 42 & 28 \\
\hline \begin{tabular}{|l} 
Tahiti Clade 4 \\
$\quad(P$. affinis/otaheitana $)$
\end{tabular} & Tahiti, Society Is. & 5 valleys & 7 sites & 9 & 8 \\
\hline Tahiti Clade 5 & Tahiti, Society Is. & 34 valleys & 41 sites & 135 & 27 \\
\hline ( $P$. claralhyalina $)$ & Mangaia, Cook Is. & & 5 sites & 6 & 1 \\
\hline & Mauke, Cook Is. & & 2 sites & 4 & 1 \\
\hline & \begin{tabular}{|l} 
Raivavae, Austral Is. \\
\end{tabular} & & 2 sites & 3 & 1 \\
\hline & \begin{tabular}{|l} 
Rimatara, Austral Is. \\
\end{tabular} & & 1 site & 5 & 2 \\
\hline & Rurutu, Austral Is. & & 4 sites & 4 & 3 \\
\hline & Tubuai, Austral Is. & & 1 site & 1 & 1 \\
\hline \begin{tabular}{|l|} 
Additional Tahitian haplotypes \\
\end{tabular} & Tahiti, Society Is. & 3 valleys & 3 sites & 4 & 3 \\
\hline Samoana attenuata (Pease, 1864) & Moorea, Society Is. & $\begin{array}{l}\text { Mt. Tohiea } \\
\text { Belvedere }\end{array}$ & 7 & 1 & 1 \\
\hline & Tahiti, Society Is. & Tiitauiri & & 1 & 1 \\
\hline & & Fareteuira & & 1 & 1 \\
\hline & & Haapupuni & & 1 & 1 \\
\hline & Raiatea, Society Is. & Mt. Toomaru & & 1 & 1 \\
\hline S. burchi Kondo, 1973 & Tahiti, Society Is. & Taravao & & 8 & 2 \\
\hline & & Mt. Atara & & 1 & 1 \\
\hline & & Mt. Aorai & & 1 & 1 \\
\hline S. diaphana Crampton \& Cooke, & Moorea, Society Is. & Hotutea & 279 & 4 & 3 \\
\hline 1953 & Tahiti, Society Is. & Mt. Aorai & & 2 & 1 \\
\hline & & Mt. Pihaaiateta & & 1 & 1 \\
\hline Eua expansa (Pease, 1872 ) & Samoa, Samoa Is. & Savaii & & 1 & 1 \\
\hline E. globosa Pilsbry \& Cooke, 1934 & \begin{tabular}{|l} 
Eua, Tonga Is. \\
\end{tabular} & & & 2 & 1 \\
\hline $\begin{array}{l}\text { E. montana (Cooke \& Crampton, } \\
1930)\end{array}$ & Samoa, Samoa Is. & Upolu & & 1 & 1 \\
\hline E. zebrina (Gould, 1946) & Samoa, Samoa Is. & & & 1 & 1 \\
\hline & American Samoa & Tutuila & & 2 & 2 \\
\hline
\end{tabular}

Figure 10

Taxonomic designations and sampling locations for Moorean partulids. Moorean samples are shaded in yellow (Burch 1970 museum), red (captive zoo) and blue (remnant wild). Summary data are also provided for non-Moorean partulids $[30,36,37]$ employed in the study. See Additional File 3 for detailed information, including museum voucher and GenBank numbers, on all the snails (Moorean and non-Moorean) incorporated into the summary phylogenetic tree (Figure I). 
easily due to an absence of indels. Maximum likelihood (ML) analyses were performed using PAUP*4.0b10 [50] under the TVM+I+G model of sequence evolution, the best-fit model selected by Akaike Information Criterion implemented in Modeltest 3.7 [51]. Likelihood parameters [base frequencies $(\mathrm{A}=0.3300, \mathrm{C}=0.1064, \mathrm{G}=$ $0.1354, \mathrm{~T}=0.4282)$; rate matrix $(1.1933,27.6197$, $1.8944,0.4618,27.6197,1)$; shape of gamma distribution $=1.2494$; proportion of invariable sites $=0.5742]$ found in Modeltest were used and heuristic searches were employed by using a neighbor-joining starting tree and nearest neighbor interchange (NNI) branch swapping. The partulid genus Eua, restricted to central Pacific islands in Samoa, American Samoa and Tonga, was used as the outgroup [42]. Initial searches found two ML trees with a log-likelihood (ln L) value of -9968.9197. Both trees were further used as starting trees for another round of heuristic search and a single ML tree ( $\ln \mathrm{L}=$-9967.6214) was recovered.

Bayesian posterior probabilities and parsimony bootstrap were employed to measure nodal support. Parsimony bootstrapping [52] was done with the "fast" stepwiseaddition option for heuristic searches (1000 replicates) using PAUP*. Bayesian analyses were performed using MrBayes 3.1.2 [53] set for the GTR $+\Gamma+I$ model. Model parameters were treated as unknown and were estimated for each analysis. Four chains were run simultaneously for $1,000,000$ generations and trees were sampled every 100 cycles. Posterior probability values were estimated by generating a $50 \%$ majority rule consensus tree after the burnin period of 2,000 using PAUP*.

\section{Authors' contributions}

DÓF and TL conceived and designed the study; TL generated the sequences and performed the phylogenetic analyses; DÓF drafted the manuscript; JBB collected and curated the 1970 museum samples; PPK collected and forwarded preserved bodies of captive specimens; TC, JYM and $\mathrm{CH}$ engaged in extensive fieldwork surveys and provided biopsies of extant populations. All authors read and approved the final manuscript.

\section{Additional material}

\section{Additional file 1}

Comparative views of Partula clara incrassa specimens sampled from Tiapa Valley (Tahiti) by T. Coote in 2007 and by H. E. Crampton during his 1906-1909 expeditions.

Click here for file

[http://www.biomedcentral.com/content/supplementary/14712148-9-204-S1.doc]

\section{Additional file 2}

Field photograph of suspected Samoana diaphana live wild specimen taken by J.-Y. Meyer on Moorea in 2008.

Click here for file

[http://www.biomedcentral.com/content/supplementary/1471-

2148-9-204-S2.doc]

\section{Additional file 3}

Table showing the taxonomic designation, sampling location, shell voucher specimen catalogue number and GenBank Accession numbers for every partulid mt COI haplotype employed in this study.

Click here for file

[http://www.biomedcentral.com/content/supplementary/14712148-9-204-S3.doc]

\section{Acknowledgements}

This work was supported by NSF DEB-0425984 award to D. Ó Foighil and J.B. Burch and by a La Direction de l'Environnement de Polynésie Française grant to T. Coote. Collection of the museum specimens was supported by NSF awards GB-3974 and GB-6450 (1965-7I) to Y. Kondo. J. Murray identified the extant Mt. Tohiea Partula taeniata simulans specimen and G. Lindsay lyophilized the Burch Moorean snail samples in 1970. Our thanks to B. Holland who kindly supplied the tissue biopsy and photograph of the Mt. Pihaiateta Samoana diaphana specimen and the Academy of Natural Science Philadelphia for a loan of Crampton's Partula clara incrassa voucher specimens.

\section{References}

I. Paulay G: Biodiversity on oceanic islands - its origin and extinction. Am Zool 1994, 34:। 34-144.

2. Baldwin BG, Sanderson MJ: Age and rate of diversification of the Hawaiian silversword alliance. Proc Natl Acad Sci USA 1998, 95:9402-9406.

3. Gillespie RG, Roderick GK: Arthropods on islands: evolution and conservation. Ann Rev Entomol 2002, 47:595-632.

4. Trewick SA, Cowie RH: Theme Issue "Evolution on Pacific islands: Darwin's legacy". Philos Trans R Soc B 2008, 363:3289-34654.

5. Carlquist S: Island Biology New York: Columbia University Press; 1974.

6. Solem A: Biogeographic significance of land snails. In Historical Biogeography, Plate Tectonics, and The Changing Environment Edited by: Gray J, Boucot AJ. Corvallis: Oregon State University Press; 1979:277-287.

7. Vermeij GJ: Inequality and the directionality of history. Am Nat 1999, I 53:243-253.

8. Hadfield MG, Miller SE, Carwile AH: The decimation of endemic Hawai'ian tree snails by alien predators. Am Zool 1993, 33:610-622.

9. Pimm SL, Moulton MP, Justice LJ: Bird extinctions in the central Pacific. Philos Trans R Soc B 1994, 344:27-33.

10. Clarke B, Murray J, Johnson MS: The extinction of endemic species by a program of biological control. Pac Sci 1984, 38:97-104.

II. Cowie RH: Evolution and extinction of Partulidae, endemic Pacific island snails. Philos Trans R Soc B 1992, 335:167-191.

12. Cowie RH: Can snails ever be effective and safe biocontrol agents? Int J Pest Manage 200I, 47:23-40.

13. Coote $T$, Loève $E$ : From $6 \mid$ species to five: endemic tree snails of the Society Islands fall prey to an ill-judged biological control programme. Oryx 2003, 37:91-96.

14. Coote T: Partulids on Tahiti: differential persistence of a minority of endemic taxa among relict populations. Am Malacol Bull 2007, 22:83-87. 
15. Murray J, Murray E, Johnson MS, Clarke B: The extinction of Partula on Moorea. Pac Sci 1988, 42: I50-153.

16. Tonge S, Bloxam Q: A review of the captive-breeding programme for Polynesian tree snails Partula spp. Internat Zoo Yearbook 1991, 30:51-59 [http://www3.interscience.wiley.com/jour nal/II 937/532/abstract? CRETRY $=$ I\&SRETRY $=0$ ].

17. Pearce-Kelly $P$, Clarke $D$, Walker $C$, Atkin $P$ : A conservation programme for the partulid tree snails of the Pacific Region. Mem Natl Mus Victoria 1997, 56:431-433.

18. Coote T, Clarke D, Hickman CS, Murray J, Pearce-Kelly P: Experimental release of endemic Partula species, extinct in the wild, into a protected area of natural habitat on Moorea. Pac Sci 2004, 58:429-434.

19. Garrett A: The terrestrial Mollusca inhabiting the Society Islands. Nat Sci Phila (Ser. 2) I884, 9:17-1/4.

20. Crampton HE: Studies on the variation, distribution and evolution of the genus Partula. The species inhabiting Tahiti. Carnegie Inst Wash Pub 1916, 228:I-3II.

21. Crampton HE: Studies on the variation, distribution and evolution of the genus Partula. The species inhabiting Moorea. Carnegie Inst Wash Pub 1932, 41 0: I-335.

22. Murray J, Clarke $B$ : The genus Partula on Moorea: speciation in progress. Proc $R$ Soc $B$ 1980, 21 I:83-1 I7.

23. Murray J, Clarke B, Johnson MS: Adaptive radiation and community structure of Partula on Moorea. Proc $R$ Soc $B 1993$, 252:205-2II.

24. Johnson MS, Murray J, Clarke B: The ecological genetics and adaptive radiation of Partula on Moorea. Oxford Surv Evolut Biol 1993, 9:167-236

25. Murray J, Stine OC, Johnson MS: The evolution of mitochondrial DNA in Partula. Heredity 1991, 66:93-104.

26. Clarke B, Johnson MS, Murray J: Clines in the genetic distance between two species of island land snails: how "molecular leakage" can mislead us about speciation. Philos Trans $R$ Soc $B$ 1996, 35 I:773-784.

27. Goodacre SL: Genetic variation in a Pacific Island land snail: population history versus current drift and selection. Proc $R$ Soc B 200I, 268:121-126.

28. Goodacre SL: Population structure, history and gene flow in a group of closely related land snails: genetic variation in Partula from the Society Islands of the Pacific. Mol Ecol 2002, I I:55-68.

29. Coote T, Loève E, Meyer JY, Clarke D: Extant populations of endemic partulids on Tahiti, French Polynesia. Oryx 1999, 33:2I5-222.

30. Lee T, Meyer JY, Burch JB, Pearce-Kelly P, Ó Foighil D: Not completely gone: two partulid tree snail species persist on the highest peak of Raiatea, French Polynesia. Oryx 2008, 42:615-619.

31. Clarke B: Balanced polymorphism and regional differentiation in land snails. In Evolution and the Environment Edited by: Drake ET. New Haven: Yale University Press, New Haven; 1968:35 I-368.

32. Clarke B, Murray J: Ecological genetics and speciation in land snails of the genus Partula. Biol J Linn Soc 1969, I:3 I-42.

33. Kondo Y: Samoana of the Society Islands (Pulmonata: Partulidae). Malac Rev 1973, 6:19-33.

34. Goodacre SL, Wade CM: Patterns of genetic variation in Pacific island land snails: the distribution of cytochrome $b$ lineages among Society Island Partula. Biol J Linn Soc 200I, 73:131-|38.

35. Johnson MS, Murray J, Clarke B: An electrophoretic analysis of phylogeny and evolutionary rates in the genus Partula from the Society Islands. Proc $R$ Soc B 1986, 227:161-177.

36. Lee T, Burch JB, Jung Y, Coote T, Pearce-Kelly P, Ó Foighil D: Tahitian tree snail mitochondrial clades survived recent massextirpation. Curr Biol 2007, I7:R502-R503.

37. Lee T, Burch JB, Coote T, Fontaine B, Gargominy O, Pearce-Kelly P, $O$ Foighil D: Prehistoric inter-archipelago trading of Polynesian tree snails leaves a conservation legacy. Proc $R$ Soc $B 2007$, 272:2907-29|4.

38. Cooke CM, Crampton HE: New species of Partula. B P Bishop Mus Occ Papers 1930, 9:3-5.

39. Kondo Y: Partulidae: preview of anatomical revision. Nautilus 1968, 81:73-77.

40. Johnson MS, Murray J, Clarke B: Parallel evolution in Marquesan partulid land snails. Biol J Linn Soc 2000, 69:577-598.
4I. Goodacre SL, Wade CM: Molecular evolutionary relationships between partulid land snails of the Pacific. Proc R Soc B 200I, 268: I-7.

42. Wade CM, Mordan PB, Clarke $B$ : A phylogeny of the land snails (Gastropoda: Pulmonata). Proc R Soc B 200I, 268:4I 3-422.

43. Johnson MS, Murray J, Clarke B: High genetic similarities and low heterozygosities in land snails of the genus Samoana from the Society Islands. Malacologia 1986, 27:97-106.

44. Gerlach J: The ecology of the carnivorous snail Euglandina rosea. In D. Phil. thesis Oxford University, Oxford, UK; 1994

45. Gerlach J: Predator, prey and pathogen interactions in introduced snail populations. Anim Conserv 200I, 4:203-209.

46. Mace GM, Purvis A: Evolutionary biology and practical conservation: bridging a widening gap. Mol Ecol 2008, 17:9-19.

47. Cowie RH, Holland BS: Molecular biogeography and diversification of the endemic terrestrial fauna of the Hawaiian Islands. Philos Trans R Soc B 2008, 363:3363-3376.

48. Gillespie RG, Claridge EM, Goodacre SL: Biogeography of the fauna of French Polynesia: diversification within and between a series of hot spot archipelagos. Philos Trans $R$ Soc Lond B 2008, 363:3335-3346.

49. Folmer O, Black M, Hoeh W, Lutz R, Vrijenhork R: DNA primers for amplification of mitochondrial cytochrome c oxidase subunit I from diverse metazoan invertebrates. Mol Mar Biol Biotechnol 1994, 3:294-299.

50. Swofford DL: PAUP*: phylogenetic analysis using parsimony (*and other methods). In Version 4 Sunderland, MA: Sinauer Associates; 2003.

51. Posada D, Crandall KA: MODELTEST: testing the model of DNA substitution. Bioinformatics 1998, 14:817-8|8.

52. Felsenstein J: Confidence limits on phylogenies: an approach using the bootstrap. Evolution 1985, 39:783-791.

53. Ronquist F, Huelsenbeck JP: MrBayes 3: Bayesian phylogenetic inference under mixed models. Bioinformatics 2003, 19:1572-1574.

Publish with Bio Med Central and every scientist can read your work free of charge

"BioMed Central will be the most significant development for disseminating the results of biomedical research in our lifetime. "

Sir Paul Nurse, Cancer Research UK

Your research papers will be:

- available free of charge to the entire biomedical community

- peer reviewed and published immediately upon acceptance

- cited in PubMed and archived on PubMed Central

- yours - you keep the copyright
BiolMedcentral 